\title{
CRONICĂ LITERARĂ
}

CZU:821.135.1.09

https://doi.org/10.52505/llf.2021.1.11

\section{DIMENSIUNILE DRAMEI EXISTENȚIALE ÎN IMAGINARUL MITOPO(I)ETIC EMINESCIAN}

\author{
Oxana GHERMAN \\ Institutul de Filologie Română „Bogdan Petriceicu-Hasdeu”
}

ORCID: https://orcid.org/0000-0001-7366-2599

Volumul „Hyperion și Demiurg. Luceafărul, mit și dramă existențială” (Iași, 2019), semnat de acad. Mihai Cimpoi, eminescolog de talie internațională, constituie un studiu de redimensionare estetică a „operei coronare a imaginarului mitopo(i)etic eminescian" prin prisma esenței tragice a Omului-Eminescu. Argumentul de forță ce legitimează o asemenea direcție a cercetării este faptul că „Luceafărul”, poemul-sinteză al Geniului Eminescian, afirmă criticul, conține - „rezumativ și quintesențial - marca ontologică a omului român”. În limbajul criptic al operei, Mihai Cimpoi intuiește nucleul unei viziuni primordiale asupra ființei naționale.

Partea liminară a volumului înglobează o diversitate uluitoare de exegeze reduse la ideile exponențiale, pe care autorul nu doar le trece în revistă, ci le interpune într-un sistem dialogal, în care tezele și ipotezele fie se contrazic până la anulare, fie se direcționează către un adevăr unanim. Unul dintre aceste adevăruri ar fi că „ființa eminesciană se înfățișează, prin aspectele fundamentale ale manifestării ei în cadrul imaginarului mitopo(i)etic, ca ființă tragică” (Cimpoi, p. 6), idee pe care criticul o probează hermeneutic, prin decodarea substratului metafizic și ontologic al operei. În susținerea tezei, Mihai Cimpoi stabilește corelații între câteva perspective critice asupra poemului „Luceafărul” și unele idei din însemnările studențești ale lui Mihai Eminescu, în care poetul descoperă cu fascinație câteva legi din fizică (precum e cea despre refracția luminii, de pildă) prin care se explică aparențele iluzorii ale lumii văzute de om, dar și conceptul de „depărtare” ca dimensiune cosmică ce generează sentimentul tragic al neființei, al infinitului. „Structurat pe o polarizare a celor două lumi - cerească și pământească, configurate în cercul larg și cercul strâmt, 
iar pe de altă parte, pe o complementare a infinitului-infinit și infinitului-finit (în sensul lui Bruno), „Luceafărul” ne apare, azi, atât ca legendă, mit, cât și ca dramă existențială” (Cimpoi, p. 11). Cu toate acestea, va remarca criticul, nașterea unui mare poet tragic dintr-un popor care $n$-are conștiința tragicului (în accepția lui C. Noica) e un paradox.

Capitolul „Ființa eminesciană” delimitează unele particularități empirice care au marcat individuația Marelui Poet. „Prima trăsătură fundamentală a ființei eminesciene, apărând ca o piatră unghiulară întemeietoare, afirmă criticul, este faptul că se gândește pe sine însăși cu o intensitate rar întâlnită. Acest preaplin al gândirii (și trăirii, bineînțeles) se impune cu adevărat ca o marcă ontologică definitorie" (Cimpoi, p. 12). Pe lângă firea profund narcisiacă, reflectată cu voluptate dionisiacă în oglinda propriei gândiri, ființa eminesciană, va completa Mihai Cimpoi, este prin excelență interogativă, ,într-o vădită strădanie de a percepe cruda taină existențială”; e chinuită de o ,irepresibilă pasiune de cunoaștere”; e o ființă cercetătoare, atrasă de gândirea originară, absorbită de teorii științifice și filosofice care procură sentimentul revelației cosmice. Conștiința Geniului Eminescian este sintetizatoare, „asigurând imaginarului mitopo(i)etic o cuprindere holistică a lumii”, este chenotică (supusă unei suferințe sfâșietoare), agitată, năzuitoare, tremurândă, aflată în „căutarea găsirii”; e un hybris generalizat, prin gradul maxim al intensităţii, conchide criticul.

În (re)descoperirea genezei poemului „Luceafărul”, Mihai Cimpoi constată un „continuum al gestației” Marelui Text din prototextul „Fata în grădina de aur” și alte hipotexte, proces în care scopul primordial a fost „căutarea esenței Ființei prin proiectarea ei într-un permanent Dincolo (de lume)” (p. 18). Sunt relevate câteva afinități ale poemului „Luceafărul” cu textele-izvoare, dar și modul în care opera se cristalizează tematic și motivic în tablourile de bază. În susținerea supozițiilor, autorul antrenează concluziile mai multor exegeți care au confruntat cele patru variante de bază ale „Luceafărului” și au identificat secvențele în care creatorul, impulsionat de o neîncetată aspirație spre perfecțiune, a operat multiple modificări în scopul adâncirii viziunilor.

Pornind de la concepțiile hegeliene asupra tragicului, criticul își orientează demersul hermeneutic, în capitolul „Aruncarea tragică în depărtare”, către relația om-destin. Sunt cercetate cele „două drame generate de nostalgia departelui cosmic și de nostalgia departelui mundan. Departele e factorul problematizant, este generator de aporii în ambele cazuri, de căderi în zona neantizatoare a irezolvabilului" (Cimpoi, p. 28). În acest sens, sunt verificate câteva concluzii de substanță ale unor eminescologi europeni, care îl determină pe M. Cimpoi 
să conchidă că „la poetul nostru, depărtarea exterioară e complementată de cea lăuntrică conform principiului novalisian că „toate drumurile duc în noi” și a celui baudelairian că nu trebuie căutat drumul, ci centrul" (Cimpoi, p. 42). Limitele și obstacolele în interpretarea poemului eminescian sunt puse în discuție în compartimentul „Orizonturile deschise și închise ale receptării”. Problema cea mai evidentă, în opinia criticului, ar fi faptul că toate percepțiile exegetice asupra „Luceafărului” se rotesc în jurul perspectivei pe care o sugerează niște note din manuscrisele lui Mihai Eminescu. Pânza interpretărilor metafizice cu privire la conștiința tragică reflectată în poemul eminescian se constituie din cercetările lui T. Maiorescu, G. Ibrăileanu, Vl. Streinu, D. Caracostea, G. Călinescu, C. Noica, G. Popa, C. Cubleșan, Bianca Osnaga, Rosa del Conte ș.a. Abordările critice poziționează poemul „Luceafărul” în lumina unor multiple reprezentări: ca „sinteză a categoriilor lirice” (T. Vianu), ca „dramă a antinomiilor” (Vl. Streinu) sau ca „dramă a existenței” (Alain Guillermou), ca „mit al cunoașterii” (G. Munteanu), ca operă ce marchează „un moment de maximă decantare a lucidității” (Pompiliu Crăciunescu), e tratat chiar și prin grilă religioasă - drept „replică individualizant-gnostică la problema creștină a întrupării” (Lucia Cifor).

O altă arie problematică o formează sfârșitul poemului „Luceafărul”, pe care însuși Eminescu îl cataloghează ca fiind un „final à la G. Bruno”, motivând astfel o analiză contextuală și comparativă (a finalurilor tuturor variantelor poemului), ce implică cercetări din sfera științifică, a teoriilor despre lumile multiple și despre codificările „rațiunii de a fi” a universului. Criticul operează cu o serie de extrase din lucrările lui G. Bruno pentru a explica viziunea care cristalizează finalul operei eminesciene: „Dacă sufletul lumii și forma universală sunt pretutindeni, postulează Bruno, acest pretutindeni nu trebuie înțeles în mod corporal și spațial, deoarece nu sunt și nu pot să fie astfel în niciun loc; ele sunt în întregime peste tot și în mod spiritual” (G. Bruno, 2002, p. 83). [...] Luceafărul ne demonstrează, prin profunda concepție eminesciano-brunoiană ce-i stă la bază, că totul se supune, în mod predeterminat, sub semnul Unului și Multiplului, al Unității acestora, vieții perpetue și ordinii ei” (Cimpoi, p. 88, 90). Mihai Cimpoi identifică tangențe surprinzătoare între viziunile astrologice, ontologice ale lui G. Bruno și cele pe care Eminescu își fundamentează concepția artistică a Marelui Poem.

Pornind de la premisa că „Omul Eminescu este prin excelență un om tragic”, în contextul în care tragismul provine din „conștiința existenței unei ordini universale sub semnul destinului și al limitelor care se pun în calea 
realizării de sine a omului" (Cimpoi, p. 92), Mihai Cimpoi aduce claritate în elucidarea cauzelor intrinseci ale tragismului eminescian. Printre motivele care alimentează sentimentul tragic se află: trăirea la limită a problematicului, a antinomiilor, descoperirea terorii timpului și a fiorului neființei, distanțarea de „cercul strâmt” și proiectarea în infinit, invadarea gândirii negativului în puterea lui legitimă de a exista în lume etc. Această complexă cauzalitate afectează conștiința tragică eminesciană, care, va concluziona criticul, „depășește fixitatea spiritului grec, mobilitatea celui german, nepăsarea eliberatoare a spiritului indian: el adaugă creștinismului cosmic liniștit al păstorului Mioriței agitația zeiască a Meșterului Manole de a depăși „cercul strâmt” prin creație și jertfire” (Cimpoi, p. 98). În înlăturarea prejudecății că Eminescu ar fi un pesimist incurabil, Mihai Cimpoi studiază natura tragismului eminescian prin grila ontologică a lui Nietzsche, ajungând la ideea că particularitatea definitorie a ființei eminesciene este anume tragismul și nu pesimismul, pentru că, spre deosebire de pesimism, tragismul contrazice renunțarea la viață.

În cea din urmă addendă la studiu, Mihai Cimpoi ne introduce în „labirintul dedalic" al celor patru versiuni plus două variante finale ale poemului (pe care prezentul volum le încorporează), al textelor înrudite și al numeroaselor cercetări ale fiecărei variante (Perpessicius, Marco Cugno, Alain Guillermou, Petru Creția ș.a.), studii care încearcă să reconstituie tabloul sinoptic al genezei poemului. Multitudinea expresiilor, inovațiilor, corectărilor și metamorfozelor pe care le suferă textul „Luceafărului” pe parcursul celor șase ani în care Eminescu lucrează intensiv la el, nu fac decât să dovedească modalitatea în care poetul își hrănea aspirația spre perfecțiune, spre absolut, cucerind eternitatea.

Conceput ca sinteză a cercetărilor de ultimă oră ale marelui eminescolog Mihai Cimpoi, volumul „Hyperion și Demiurg. Luceafărul, mit și dramă existențială” (Iași, 2019) invită, așadar, la o lectură laborioasă, pluriperspectivistă, ce trimite spre un impresionant număr de studii dedicate poemului „Luceafărul”, înglobând multiple încercări de decriptare a dramei existențiale din substratul ontologic al operei.

\section{Referințe bibliografice:}

1 BRUNO, Giordano. Opere italiene II. Despre cauză, principiu și unu. București: Humanitas, 2002.

2 CIMPOI, Mihai. Hyperion și Demiurg. Luceafărul, mit și dramă existențială. Iași: Multimedia, 2019. 
Notă. Cronica a fost realizată în cadrul proiectului de cercetare 20.80009.1606.03 Contexte socio-culturale autohtone și interconexiuni europene în creația populară și literatura cultă din Basarabia (sec. XIX până în prezent), Institutul de Filologie Română „Bogdan Petriceicu-Hasdeu” al MECC. 